\title{
Produzir subjetividades: o que significa?
}

\section{Producing subjectivity: What does it means?}

\author{
Leonardo Barros Soares ${ }^{*}$ \\ Formando do curso de Psicologia da Universidade Federal do Ceará - UFC, Fortaleza, \\ Ceará, Brasil
}

\section{Luciana Lobo Miranda **}

Professora do Programa de Pós-Graduação em Psicologia da Universidade Federal do Ceará - UFC, Fortaleza, Ceará, Brasil

\begin{abstract}
Resumo
O presente artigo tem como finalidade discutir a temática da produção de subjetividade a partir dos escritos do pensador francês Félix Guattari. Para tanto lançamos mão de uma leitura crítico-interpretativa de seus textos e de alguns de seus comentadores e colaboradores, iniciando a discussão pelos aportes que nos conduza à delimitação do conceito de produção de subjetividade. Discorremos sobre como a subjetividade foi percebida na tradição platônico-hegeliana em contraponto com a visão empirista, através da leitura de Gilles Deleuze da obra de David Hume. Para melhor compreensão dos processos de subjetivação na contemporaneidade, tomamos as noções de máquina e de Agenciamento Coletivo de Enunciação, problematizando a dinâmica dos processos de assujeitamento e singularização da subjetividade no contexto do Capitalismo Mundial Integrado.
\end{abstract}

Palavras-chave: Subjetividade, Máquina, Agenciamento coletivo de enunciação.

\begin{abstract}
This article aims to serve as an introduction to the theme of the production of subjectivity from the writings of French thinker Felix Guattari. For both launched hand of a critical-reading of their interpretative texts and some of its commentators and employees, starting the discussion of the issue of subjectivity seeking contributions for a better definition of a conceptual subjectivity that is produced. This route about the subjectivity was perceived within a tradition platonic as opposed to the empiric vision from the reading of David Hume carried out by Gilles Deleuze. Then we have wrote around the notions of machine and Agency Collective of Enunciation, theoretical constructs important for a better understanding of real processes of production of subjectivity in the context of the Integrated Global Capitalism.
\end{abstract}

Keywords: Subjectivity, Machine, Agenciamento group enunciation. 
A única finalidade aceitável das atividades humanas é a produção de uma subjetividade que enriqueça de modo contínuo sua relação com 0 mundo. Félix Guattari, (1992, p.33).

Ao observarmos um quadro, admirarmos a beleza de uma pessoa ou no momento da escolha do curso para o qual prestaremos o vestibular, ao devanearmos à beira-mar, lembrando-nos de nossos amores passados, ou ao sonharmos com nosso futuro, às vezes incerto, às vezes promissor, ao ouvirmos aquela música que nos leva para longe, à nossa terra natal, ou que nos remete a um olhar, a um pôr do sol, a uma brisa suave soprando nos cabelos, poucos de nós então teriam dificuldades em classificar essas cenas como "subjetivas", como fazendo parte da "subjetividade" de um indivíduo. Mas afinal, quando falamos de nossos sonhos, desejos, fantasias, esperanças, percepções, medos, anseios, pensamentos e lembranças, do que estamos tratando? O que está em jogo quando dissertamos acerca da subjetividade?

Não é raro escutarmos em nossas conversas com amigos, ou professores, ou ainda nos programas de televisão, a utilização do termo "subjetividade", empregado ora para qualificar - "é preciso levar em conta a subjetividade do paciente para um tratamento mais humanizado" - ora para desqualificar uma escolha ou ponto de vista- "os critérios subjetivos não nos conferem uma segurança científica". Espécie de pressuposto ontológico oculto das psicologias, muitas vezes tratamos do tema "subjetividade" cotidianamente nos bancos das universidades sem nos lançarmos à análise cuidadosa do conceito.

O presente trabalho pretende trazer a discussão sobre as implicações teórico-práticas ao considerar a subjetividade sob o prisma da produção, tendo como referência a obra de Félix Guattari. Antes, porém, cabe recorrer à pergunta fundamental, ponto de partida para todas as análises posteriores: o que entendemos aqui, afinal, por subjetividade?

Como se trata aqui de uma pesquisa eminentemente teórica, a metodologia utilizada fundamentou-se nos textos que consideramos fundamentais para delimitação conceitual do tema. Cabe ressaltar, entretanto, que não nos deteremos numa "leitura-comentário" das obras, mas, antes, encaramos a leitura como gesto, obra, prática, "assalto". O que faremos aqui é uma leitura multidimensional, crítico-interpretaviva e intertextual (PAIVA, 2000). É no entrecruzamento e, por vezes, afrontamento de percursos teóricos diversos que ensejamos a construção de diálogos criativos capazes de trazer novos elementos às discussões sobre o conceito de subjetividade nas ciências psicológicas.

Seguiremos tão somente uma linha argumentativa que visa tornar mais claro o conceito de "produção de subjetividade" proposto por Félix Guattari (1988, 1990, 1992, 1993), assim como de que forma a melhor 
compreensão desta concepção se torna fundamental quando se quer entender de que maneiras são engendradas as mais diversas formas de ver, sentir e estar no mundo.

Para tal empreendimento será preciso introduzir, em um primeiro momento, aportes diferentes quanto à noção de subjetividade, a partir tanto da perspectiva de subjetividade substancial quanto da subjetividade produzida. O segundo ponto explorará a subjetividade como processo, através dos conceitos de máquina e de agenciamentos coletivos de enunciação. No terceiro e último momento, serão apresentadas as características de uma produção de subjetividade(s) que engendram assujeitamentos e singularizações no contexto de um Capitalismo Mundial Integrado (CMI).

\section{I - Aportes para um conceito de subjetividade: Verticalidade e horizontalidade na Geografia do Pensamento}

A discussão sobre o tema da subjetividade não é uma exclusividade do campo das ciências psicológicas. Há muito a filosofia se debruça de formas diversas e em momentos históricos diferentes sobre a questão, dando lugar à pluralidade de concepções que torna exaustiva a tarefa de delimitação conceitual mais abrangente acerca do termo. Entendemos, todavia, a necessidade de tratar das vicissitudes do conceito de subjetividade na tradição filosófica ocidental, suas conformações teóricas e suas implicações no curso do pensamento moderno.

Garcia- Roza (1988), citando Deleuze, afirma que, para este autor, além de uma história do pensamento ocidental, também poderíamos traçar-lhe uma geografia. O pensamento se moveria em função de dois grandes eixos, a saber, um eixo vertical, dos conhecimentos, da episteme - cujo maior representante é o platonismo - e um eixo horizontal, o dos acontecimentos - na qual se encontra a tradição filosófica das escolas cínicas e sofistas". Em sua "orientação ascendente", o objetivo do filósofo platônico é o de alcançar, através da filosofia e da ciência, o "lugar nas alturas" da idéia, da essência, do inteligível, do modelo. Na direção contrária, mas ainda no mesmo eixo, encontram-se os filósofos présocráticos interessados na busca da arché, da substância de todas as coisas do universo $\underline{2}$. Para os filósofos da "horizontalidade", porém, a "verdade" não residiria nem no céu platônico nem nas profundezas présocráticas, mas, antes na superfície do acontecimento.

Como sintetiza Garcia-Roza (1988), o objetivo final da filosofia de Platão é a produção do discurso universal, que coincidirá com a realização plena da Razão e a revelação do Ser em sua totalidade. Ao privilegiar a verticalidade do pensamento e com ela a relação modelo-cópia, o platonismo teria fundado o domínio que a filosofia ocidental reconhecerá 
como seu: o domínio da representação, que será posteriormente desenvolvido por Aristóteles na descrição dos modos de hierarquização e diferenciação das espécies animais e vegetais, suas propriedades e essências (CHAUÍ, 2002; FREIRE, 1997).

Guardemos a assertiva deleuziana (apud GARCIA-ROZA, 1988) de que é a representação que irá ser reconhecida como o domínio próprio da filosofia durante todo o seu posterior desenvolvimento. A discussão sobre a relação entre "o mundo de fora" e "mundo de dentro", o mundo sensível e o mundo inteligível, em suma, a questão da representação, iniciada pelo platonismo, se constituirá, finalmente, como problema a ser investigado somente quando René Descartes formular pela primeira vez a questão da subjetividade como objeto de meditação filosófica. Será justamente esta concepção representacional do conhecimento do mundo, como veremos a seguir, que será profundamente abalada pelas investigações sobre a natureza humana de David Hume.

A identificação da subjetividade com a consciência e suas consequentes derivações- um "Eu" racional, autônomo, e individualizado - parece ser um ponto inabalável da filosofia moderna, a partir das meditações cartesianas (GARCIA-ROZA, 1988). Em termos esquemáticos e simplificados, a consciência como subjetividade estaria referida e se constituiria através destas instâncias - eu, pessoa, cidadão e sujeito - e seria ativa, sede da razão e do pensamento, capaz de identidade consigo mesma, sujeito de direitos, virtude e verdade (COSTA, 1998). Criam-se assim duas esferas autônomas e interativas, cortadas de suas realidades políticas, culturais, produtivas - um sujeito a um só tempo pensante e autobiografável, que conhece o mundo, e um objeto dado a priori que espera ser desvelado em sua intimidade pelo primeiro (MANGUEIRA, 2001).

A partir do século XIX, ao tentar afirmar-se paulatinamente como saber científico, distinto das especulações filosóficas, a psicologia começa a reivindicar para si, como objeto de seu saber, a subjetividade. 0 distanciamento gradual das práticas de ensino dos mosteiros medievais e o surgimento dos institutos de ensino (e posteriormente as escolas), a mudança do papel do Estado, as transformações econômicas e sociais, características da era industrial, o liberalismo econômico e o desenvolvimento de um saber médico-psiquiátrico, aliado às metodologias estatísticas de recenseamento populacional, prepararam o pano de fundo histórico para o surgimento de um saber que se preocupasse com a higiene das massas e dos indivíduos comuns. A ciência psicológica surge, em resumo, como um saber individualista e individualizante, focando, na massa de corpos indiscerníveis das crescentes cidades européias, um indivíduo singular (FOUCAULT, 1987), “dotado de uma subjetividade substancial, [...] uma espécie de núcleo íntimo. E a Psicologia não é só o saber que descreve como também explica e, de certa forma, detecta esse 
recôndito da alma humana. (ALBUQUERQUE, apud MIRANDA, 2000, p. 31)".

Mesmo adquirido o epíteto de ciência a partir do advento das experiências de Wundt e seus seguidores, e constituindo posteriormente um considerável edifício teórico-metodológico tão plural, ainda assim, o que está em jogo, desde o nascimento desta psicologia dos indivíduos, é o tema platônico da altura que é refletida, como num espelho que mirasse as nuvens, na profundidade da consciência. Eis a verdade do sujeito como representação.

Entender a proposta "geográfica" do pensamento de Deleuze é fundamental à discussão aqui empreendida para observar as transformações do conceito de subjetividade. Desde a concepção substancial até a "maquínica", essas transformações seguem o caminho de uma lenta e progressiva mudança de orientação no curso do pensamento filosófico ocidental: do eixo vertical (que poderíamos chamar de eixo fundacional), que conforme foi visto, estabelece bases sólidas para os sistemas filosóficos, para o eixo horizontal, ou "eixo conectivo", "rizomático", que desmonta o fundamento último das coisas e revela seu caráter fragmentário, descontínuo e acidental.

Retirado da botânica, o conceito de rizoma distingue-se da imagem da raiz, pois suas hastes compreendem verdadeiras redes sem um eixo principal. Tal conceito, proposto em Mil Platôs (1995), consiste em um enfrentamento à visão de mundo eminentemente universalista e dicotômica, marcante no mundo ocidental ${ }^{3}$. Desta forma, a importância da noção de rizoma na obra de Deleuze e Guattari é capital, posto que é a subversão de uma "imagem dogmática do pensamento" que procede por hierarquizações, categorias estáveis (identidade, consciência, poder) em prol de uma outra concepção de pensamento, que é puro movimento criador:

\begin{abstract}
Resumamos os principais caracteres de um rizoma [...]. Ele não é feito de unidades, mas de dimensões, ou antes de direções movediças. Ele não tem começo nem fim, mas sempre um meio pelo qual ele cresce e transborda. Ele constitui multiplicidades lineares a $\mathrm{n}$ dimensões, sem sujeito nem objeto [...]. Oposto a uma estrutura, [...], o rizoma é feito somente de linhas.[...] 0 rizoma é uma antigenealogia. É uma memória curta ou uma antimemória. O rizoma procede por variação, expansão, conquista, captura, picada. [...], o rizoma se refere a um mapa que deve ser produzido, construído, sempre desmontável, conectável, reversível, modificável, com múltiplas entradas e saídas, com suas linhas de fuga. [...] unicamente definido por uma circulação de estados [...] todo tipo de "devires". (DELEUZE; GUATTARI, 1995, p.32).
\end{abstract}

Será justamente a mudança de orientação do eixo do pensamento que vai da valorização da verticalidade (altura e profundeza, fundamento e 
hierarquia), para a consideração da horizontalidade (associação, aliança e conexão) numa perspectiva rizomática que marcará de forma definitiva a ruptura com a tradição platônica do pensamento e dará lugar ao desenvolvimento de uma filosofia do acontecimento, e que colocará em outros termos a problemática da subjetividade.

Dentro da rubrica do que se chama usualmente de empirismo, que abriga pensadores tão diversos quanto Berkeley e Locke, concordamos com Garcia-Roza (1988) e com Mangueira (2001) quando estes apontam, no texto deleuziano, a promoção de David Hume como aquele que levou a cabo de forma mais consistente a crítica ao projeto platônico-hegeliano hegemônico na filosofia ocidental.

A filosofia de Hume é uma crítica aguda da representação. Hume não faz uma crítica das relações, mas uma crítica das representações, justamente porque estas não podem apresentar as relações. Fazendo da representação um critério, colocando a idéia na razão, o racionalismo colocou na idéia aquilo que não se deixa dar sem contradição numa idéia, a generalidade da própria idéia e a existência do objeto, o conteúdo das palavras sempre universal, necessário ou verdadeiro"; (DELEUZE, 2001, p.22, grifo do autor)

Deleuze (Id. Ibid.) analisa Hume como uma das principais contribuições do empirismo para uma concepção de subjetividade não substancializada e imanente, forjada no seio do socius e constitutiva de uma filosofia do acontecimento, localizada no eixo horizontal do pensamento, segundo a topologia deleuziana.

A partir das afirmações de Hume segundo as quais "as relações são exteriores aos termos" 4 e de que o associacionismo é a lógica das relações entre os termos ${ }^{5}$, podemos destacar alguns pontos. Primeiro, que 0 projeto cartesiano de fazer coincidir pensamento e ser, sujeito e subjetividade, já não faz mais sentido, pois a subjetividade não é mais do que uma coleção de dados sem ordem (Id.,I bid.), sem estrutura e sem lei, e não coincide com o sujeito porque este é apenas um efeito das articulações às quais as idéias estão submetidas. Segundo, que a lógica identitária dos termos é substituída pela lógica do encontro, que substitui o verbo Ser (A é B) pela conjunção "e" (A e B) $)^{\underline{6}}$. Torna-se, portanto, impossível falar de consciência como algo que é intenção, razão, pensamento, e de subjetividade como sinônimo de sujeito.

Desta feita, o que faz então com que nos orientemos no mundo segundo alguns padrões estabelecidos, consagrados, e que experimentamos como totalidade indivisível, como identidade? A resposta de Hume é simples, mas não menos intrigante: é na repetição da experiência, ou seja, no hábito de adquirir hábitos, que forjamos isso que chamamos de espírito, alma, consciência, subjetividade. (DELEUZE, 2001).

O sujeito é, pois, tão somente duração, persistência no tempo de um conjunto de afirmações e crenças decorrentes dos hábitos que qualificam 
o individuo e the conferem não "a identidade", mas "uma identidade", por definição provisória, que será passível de mudança tão logo mudem as experiências que conformam seus hábitos.

Já podemos ver aqui o novo panorama para discussão do tema da subjetividade. Não é possível falar de subjetividade em geral nem de Sujeito Universal, mas somente de subjetividades práticas e sujeitos que se constituem na experiência social, em seus trajetos singulares na sua família, na escola, na rua, no seu corpo, na caserna, no escritório, etc:

Que não haja nem possa haver subjetividade teórica vem a ser a proposição fundamental do empirismo. E, olhando bem, isso é tãosó uma outra maneira de dizer: o sujeito se constitui no dado. Se o sujeito se constitui no dado, somente há, com efeito, sujeito prático. (DELEUZE, 2001, p.118)

Não estamos mais no mundo das representações e das essências que caracteriza o pensamento platônico/hegeliano, mas dos acontecimentos cotidianos e prosaicos, nos quais nos movemos e nos constituímos. Ora, se é na repetição dos hábitos e nas relações estabelecidas entre os termos que o que chamamos de "espírito" se constitui, já se pode entrever uma subjetividade material (ainda que incorpórea porque produzida por sentidos), imanente (porque se forja sempre neste mundo e com as coisas que dele fazem parte), marcadamente relacional (ao contrário do solipsismo racional do sujeito epistêmico cartesiano), associacionista e interativa, porque é apenas na interação entre matéria-sensível e matériavibrátil (sons e tímpano, cores e olho, calor e pele, em suma, relação entre termos) que se forja o "espírito". $\underline{7}$

Considerar a subjetividade sob o ângulo de sua materialidade é levar em conta seu caráter processual, parcial, imanente, pré-pessoal (na medida em que antecede a qualquer sujeito individuado, porque o constitui, polifônico (no sentido bakthiniano do termo ${ }^{8}$ ), coletivo e maquínico. Mas, antes de tentar precisar o que estes termos querem dizer, a partir da concepção de Hume da subjetividade, podemos afirmar com Guattari que Não existe uma subjetividade do tipo "recipiente" em que se colocariam coisas essencialmente exteriores, as quais seriam "interiorizadas". As tais "coisas" são elementos que intervêm na própria sintagmática da subjetivação inconsciente. São exemplos de "coisas" desse tipo: um certo jeito de utilizar a linguagem, de se articular ao modo de semiotização coletiva (sobretudo da mídia) ; uma relação com o universo das tomadas elétricas, nas quais se pode ser eletrocutado; uma relação com o universo de circulação na cidade. Todos esses são elementos constitutivos da subjetividade. (GUATTARI; ROLNIK 1999. p.34)

A relação com o universo das tomadas elétricas, dos transportes, das cores, dos sons, o mundo dos sonhos, dos desejos, dos afetos, do pensamento e do saber, os modos como se conformam as relações 
consigo mesmo e com os outros, os modos de ver mundo, de encarar as agruras do cotidiano, de se vestir, de falar, de amar e de sentir... enfim, os modos de existência.

Mas se as subjetividades, essa relação de si consigo mesmo e com as outras coisas do mundo, os modos de existir, são produzidas, cabe a pergunta: quem ou o quê produz subjetividade e quais são as condições desta produção? Não estaríamos desta forma reproduzindo a dicotomia entre sujeitos e objetos, tema clássico do "eixo filosófico vertical", na separação entre objetos produtores e sujeitos consumidores de subjetividade? Como funciona o conceito de máquina na superação desta dicotomia? A pertinência ou não destas perguntas e a tentativa de elucidação serão levadas a cabo nos tópicos seguintes.

\section{II- Subjetividade(s) produzida(s) e produtora(s): afinal, o que significa?}

Conforme vimos no primeiro ponto deste trabalho, cortadas de suas realidades políticas, de suas condições de produção, de sua polifonia constitutiva e de seu caráter processual, as subjetividades se particularizam, se autonomizam na esfera individual e se tornam idiossincrasias, uma "questão de gosto" remetidas a uma instância oculta, a uma "alma" descolada do corpo, sede do entendimento, da razão e das emoções do sujeito. Já considerar a subjetividade a partir do ângulo da produção, assim como o proposto por Guattari aproxima-se, a nosso ver, da perspectiva de Hume, que advoga em favor de um sujeito prático que conforma uma subjetividade igualmente prática ${ }^{9}$.

Fim das relações de complementaridade entre altura e profundidade, reviravolta radical nos conceitos de subjetividade e de sujeito. Não mais a representação do mundo na consciência de um sujeito autônomo, mas a assunção de uma floresta de objetos e de signos concatenados para formar um gosto, um jeito de vestir, um modo de viver. Não mais falar em sujeito como um être-là, dado a priori, mas em agenciamentos coletivos de enunciação, concerto polifônico de vozes, devires imperceptíveis, mutações afetivas e outras sensibilidades (GUATTARI; ROLNIK, 1999). Descentramento da questão do sujeito para a da produção de subjetividade, pois esta, como nos diz Guattari (Ibid., p.28) "constitui matéria-prima de toda e qualquer produção".

Ora, ao considerarmos a subjetividade como um fluxo contínuo de sensações, modos de existir, amar e comunicar, de imagens, sons, afetos, valores e formas de consumo literalmente fabricadas no entrecruzamento de instâncias sociais, técnicas, institucionais e individuais, estamos radicalizando as possibilidades dos engendramentos de subjetividades. No limite, é possível talvez considerar que todos os sujeitos e coletivos 
humanos, institucionalizados ou não, com maior ou menor grau de instrução e de conhecimento tecnológico, são produtores de subjetividade. As condições de produção evocadas nesse esboço de redefinição implicam, então, conjuntamente instâncias humanas inter-subjetivas manifestadas pela linguagem e instâncias sugestivas ou identificatórias concernentes à etologia, interações institucionais de diferentes naturezas, dispositivos maquínicos, tais como aqueles que recorrem ao trabalho com computador, Universos de referência incorporais tais como aqueles relativos à música e às artes plásticas. Essa parte não-humana pré-pessoal é essencial, já que é a partir dela que pode desenvolver sua heterogênese. (GUATTARI, 1992, p.20)

Chegamos então a uma definição provisória do o que estamos chamando aqui de subjetividade: tudo aquilo que concorre para a produção de um "si", um modo de existir, um estilo de existência. Mas, outras perguntas

se fazem necessárias para a continuidade da problematização apresentada. A primeira destas indagações é: se a subjetividade, esse modo de se relacionar com o mundo, considerado fruto de uma "engenharia de altas interações" de componentes heterogêneos, é produzida, o que (ou quem), então, de fato a produz?

\section{III - O que produz subjetividade? Um estranho mundo feito de máquinas e de Agenciamentos Coletivos de Enunciação...}

De uma maneira mais geral, dever-se-á admitir que cada indivíduo, cada grupo social veicula seu próprio sistema de modelização da subjetividade, quer dizer, uma certa cartografia feita de demarcações cognitivas, mas também místicas, rituais, sintomatológicas, a partir da qual ela se posiciona em relação aos seus afetos, suas angústias e tenta gerir suas inibições e suas pulsões. (GUATTARI, 1992, p.21)

A partir da leitura do trecho acima poder-se-ia inferir daí que todos os seres humanos, adultos, crianças, idosos, homens e mulheres, assim como todos os grupos sociais, sejam eles grupos de oração, amigos conversando ou megacorporações bancárias e midiáticas, produzem processos de subjetividade (ou subjetivações). Numa definição mais refinada, porém, o mesmo autor é categórico ao afirmar que:

A subjetividade é produzida por agenciamentos de enunciação. Os processos de subjetivação, de semiotização - ou seja, toda a produção de sentido, de eficiência semiótica - não são centrados em agentes individuais (no funcionamento de instâncias intrapsíquicas, egóicas, microssociais), nem em agentes grupais. Esses processos são duplamente descentrados. Implicam o funcionamento de máquinas de expressão que podem ser tanto de natureza extra-pessoal, extra-individual (sistemas maquínicos, econômicos, sociais, tecnológicos, icônicos, ecológicos, etológicos, 
de mídia, enfim sistemas que não são mais imediatamente antropológicos), quanto de natureza infra-humana, infrapsíquica, infrapessoal (sistemas de percepção, de sensibilidade, de afeto, de representação, de imagens, de valor, modos de memorização e produção de idéia, sistemas de inibição e de automatismos, sistemas corporais, orgânicos, biológicos, fisiológicos, etc.). (GUATTARI E ROLNIK, 1999. p.31)

Neste sentido, concordamos com Gonzalez-Rey (2003) quando este localiza Guattari como um "autor de cosmovisão marxista" gerador de um núcleo teórico próprio. A dimensão da produção, de óbvia fonte marxista, embora não centrado no eixo da economia, é tema recorrente em toda sua obra com Gilles Deleuze e, se estamos falando de produção, é forçoso também que falemos igualmente de máquinas e de agenciamentos coletivos.

O conceito de máquina é um dos conceitos mais herméticos e, não obstante, importantes em todo o vocabulário daqueles autores. Oliveira (2005) explica que as máquinas, para Guattari não se referem ao espaço purificado das técnicas (LATOUR, 1994), mas a uma organização de fluxos e forças plurais e heterogêneas, ou seja, são "acoplamentos heterogêneos que agenciam". Máquina, nesta acepção, indica a tentativa de substituição da linguagem idealista de almas e sujeitos caracterizados como "agências puras" para enfatizar não o que o sujeito é, mas sublinhando o que ele faz, repudiando, desta forma, a esfera da ontologia clássica e as teorias estruturalistas (OLIVEIRA, 2005).

É importante que sublinhar que a noção de máquina repudia a esfera da ontologia "fundacional", que privilegia o Ser e consiste numa tentativa de abandonar o velho vocabulário que remete ao sujeito como uma agência, uma instância pura, aquele sujeito racional referido na primeira parte deste trabalho. Esta consideração é de suma importância, pois é neste mundo "híbrido" de "quase-sujeitos" e "quase-objetos" (LATOUR, 1994), nesse "entre", que as coisas se engancham, se acoplam e agenciam elementos vários. É nesse intermezzo, puro campo de possíveis, que as fronteiras entre sujeito e objeto se diluem, se tornam inócuas, e as existências vão se delineando, as subjetividades sendo produzidas. É a mecanosfera, e não a biosfera, o ambiente maquínico do mundo.

Segundo Broeckmann (2001), em Guattari o maquínico não está necessariamente ligado a objetos tecnológicos ou mecânicos:

As máquinas podem ser corpos sociais, complexos industriais, formações psicológicas ou culturais, bem como complexos de desejos agenciando indivíduos, materiais, instrumentos, regras e convenções que, em conjunto, constituem-se máquina. As máquinas são junções de pedaços heterogêneos, a agregação que transforma as forças, articula e impulsiona seus elementos e os coloca em estado de contínua transformação. (Id., Ibid. 2001, p.116, tradução nossa). 
Máquinas de subjetivação linguística, psicanalítica, midiática, literária, familiar, monacal, empresarial, comunitária, hospitalar, militar, estatal, monetária, publicitária. A partir do prisma da subjetividade como produção, percebemos, enfim, que habitamos um estranho mundo povoado de máquinas por todos os lados. Estamos, desde sempre, entrando em máquinas com o mundo. Deve-se reconhecer, como fez Guattari (1993), que a subjetividade sempre esteve relacionada a equipamentos maquínicos tais como os "monacais" na Idade Média ou os aristocráticos, como a Corte de Versalhes.

O conceito de agenciamento de Deleuze e Guattari, por seu turno, diz respeito ao acoplamento de um conjunto de relações materiais a um regime de signos correspondente. O agenciamento é formado pela expressão (agenciamento coletivo de enunciação) e pelo conteúdo (agenciamento maquínico) (DELEUZE; GUATTARI, 1995). Trata-se de uma correlação entre duas faces inseparáveis. A expressão refere-se ao conteúdo sem descrevê-lo ou representá-lo, mas intervém nele. Como exemplos de agenciamentos coletivos de enunciação poderíamos citar os agenciamentos judicial, familiar, escolar, midiáticos, dentre outros.

Noção substitutiva das idéias de sujeito de enunciação ou das instâncias psíquicas de Freud, o(s) agenciamento(s) não diz(em) respeito nem a uma entidade individuada nem a uma entidade social predeterminada. Segundo Caiafa (2000), tomar a enunciação como agenciamento significa descentrá-la do sujeito e da relação emissor-receptor, potencializando, ao contrário, a indissociabilidade dos agenciamentos de enunciação de práticas concretas e das relações de poder. O conceito de agenciamento coletivo de enunciação tem forte articulação com a pragmática bakhtiniana. Em Caosmose (1992) o caráter coletivo da subjetividade insere-se na mesma perspectiva em relação à linguagem em Bakhtin. Em Mil Platôs (1995) o discurso indireto livre do pensador russo, no qual o sujeito do enunciado e da enunciação se confunde numa só voz, coloca-se como forte interlocutor da pragmática de Deleuze e Guattari para pensar os Agenciamentos Coletivos de Enunciação. Segundo estes autores, Bakhtin e Labov insistiram de duas formas diferentes, no caráter social da enunciação opondo-se não apenas ao subjetivismo, mas ao estruturalismo (DELEUZE; GUATTARI, 1995, p.17).

Lembremo-nos, a título de exemplo, um início de dia em alguma família de classe média brasileira. Os filhos tomando café da manhã em frente à televisão, o cachorro latindo e mãe preocupada com os afazeres domésticos, o "corre-corre" para apressar as crianças para irem à escola. Latidos estridentes, comerciais na televisão, as admoestações da mãe aos filhos que se engalfinham ou que troçam uns dos outros. A campanhinha toca, o alarme do carro dispara, pode-se ouvir uma música ao longe. Neste burburinho, concerto de vozes e ruídos inumanos, quem está 
falando? A pergunta pelas instâncias definidas de enunciação de discurso já não parece fazer mais sentido, pois o que se tem efetivamente é uma multidão de vozes, a polifonia familiar matutina.

\section{Como estamos produzindo subjetividade? Assujeitamento e singularização no Capitalismo Mundial Integrado.}

Subjetividades sendo produzidas por todos os lados em agenciamentos insuspeitos, materializando-se no cotidiano, em nossas relações familiares, afetivas, institucionais, libidinais. Nesse "admirável mundo novo" povoado de máquinas de subjetivação a nós apresentado por Deleuze e Guattari, talvez se possa lançar a pergunta acerca das características da produção de subjetividade(s) na contemporaneidade. Em que contexto sócio-histórico ela se dá, e que subjetividades são majoritariamente produzidas? Há de fato uma produção de subjetividade(s) altamente diferenciada(s) ou, ao contrário, o que se tem é uma função subjetiva hegemônica e homogeneizante de todas as outras formas de existir?

Guattari é enfático ao afirmar que a distinção entre cultura popular e cultura erudita é um falso problema, pois o que há é apenas "uma cultura capitalística que permeia todos os campos de expressão semiótica" (GUATTARI; ROLNIK, 1999, p. 23). O acréscimo do sufixo "ístico" ao termo "capitalista" produziu um neologismo que traduz a noção de que a cartografia subjetiva de áreas do terceiro mundo e de países exintegrantes do bloco socialista do leste europeu segue padrões semelhantes de constituição dos países industrializados da vanguarda capitalista (Id., I bid.).

O CMI afirma-se, em modalidades que variam de acordo com o país ou com a camada social, através de uma dupla opressão. Primeiro, pela repressão direta no plano econômico e social- o controle da produção de bens e das relações sociais através de meios de coerção material externa e sugestão de conteúdos de significação. A segunda opressão, de igual ou maior intensidade que a primeira, consiste em o CMI instalar-se na própria produção de subjetividade: uma imensa máquina produtiva de uma subjetividade industrializada e nivelada em escala mundial tornou-se dado de base na formação da força coletiva de trabalho e da força de controle social coletivo (Id, I bid., p.39, grifo do autor).

Poderíamos pensar, por exemplo, na intensa produção de subjetividade capitalística que existiu na tensa relação entre as duas Alemanhas à época da Guerra Fria, ou nas mutações subjetivas que ocorreram na Rússia e Polônia pós-URSS. Mais recentemente, poderíamos pensar em toda a 
esmagadora produção de subjetividade que deverá se intensificar em Cuba, com o fim do regime Castrista.

O cenário contemporâneo, portanto, conforma o que Guattari chamou de Capitalismo Mundial Integrado (CMI), período histórico marcado pela expansão e consolidação da hegemonia do modo de produção capitalista em nível planetário (Id., Ibid.). Num mundo onde o Capital é o referente geral das relações humanas, independentes das chamadas ideologias políticas que na atualidade tornaram-se indiscerníveis, assiste-se atônito à mercantilização e à massificação dos modos de vestir, de se alimentar, de sentir, de amar, de consumir:

\begin{abstract}
A ordem capitalística produz os modos das relações humanas até em suas representações inconscientes: os modos como se trabalha, como se é ensinado, como se ama, como se trepa, como se fala, etc. Ela fabrica a relação com a produção, com a natureza, com os fatos, com o movimento, com o corpo, com a alimentação, com o presente, com o passado e com o futuro- em suma, ela fabrica a relação do homem com o mundo e consigo mesmo. (GUATTARI; ROLNIK, 1999, p.42)
\end{abstract}

Anda-se numa rua em Fortaleza, Rio de Janeiro, Berlim ou Amsterdã; veste-se o jeans, come-se numa das lojas de uma imensa cadeia de fastfood, e ao fim do dia assiste-se à festa de premiação do Oscar ou aos jogos olímpicos, o que significa uma gigantesca soma de bilhões de telespectadores em todo o mundo. Fabricação de indivíduos massificados em meio à produção generalizada de uma subjetividade assujeitada, laminada em sua potência de invenção.

$\mathrm{Na}$ esteira deste percurso cabe ainda indagar: em meio à produção massiva em nível mundial de certos modos de agir, vestir e amar veiculados hodiernamente pelos mass-media e consumidos por multidões, é possível pensar em produzir subjetividades singulares e singularizantes, que escapem às modelizações dominantes?

A este propósito esclarece o texto de Miranda (2000) afirmando que se a subjetivação contemporânea se encontra inexoravelmente ancorada em dispositivos capitalistas, isso não significa o seu aprisionamento absoluto. É sempre possível resistir ao presente, escapar das modelizações dominantes, apropriar-se diferentemente do que nos é oferecido cotidianamente pela televisão, pelo cinema, pelo patrão, pelo cônjuge, pela escola ou pelo outdoor, pois "esse desenvolvimento da subjetividade capitalística traz imensas possibilidades de desvio e singularização" (GUATTARI; ROLNIK, 1999). Em suma, é sempre possível atrever-se a singularizar (DELEUZE, 1997; GUATTARI; ROLNIK, 1999).

A essa máquina de produção de subjetividade eu oporia a idéia de que é possível desenvolver modos de subjetivação singulares, aquilo que poderíamos chamar de 'processos de singularização', uma maneira de recusar esses modos de encodificação preestabelecidos, todos esses 
modos de manipulação e tele comando, recusá-los para construir, de certa forma, modos de sensibilidade, modos de relação com o outro, modos de produção, modos de criatividade que produzam uma subjetividade singular. Uma singularização existencial que coincida com um desejo, com um gosto de viver, com uma vontade de construir o mundo no qual nos encontramos, com a instauração de dispositivos para mudar os tipos de sociedade, os tipos de valores que não são os nossos. (GUATTARI; ROLNIK, 1999, p.16-17, grifo do autor)

Os novos movimentos sociais antiglobalização parecem corroborar as afirmações de Guattari. Concomitante à expansão em escala planetária das multinacionais assiste-se ao surgimento de movimentos de resistência de vários matizes que vão desde um inofensivo arremessar de tortas a ações espetaculares, que pretendem a polêmica, tais como os protestos do grupo Greenpeace, passando pelos movimentos de software, conhecimento e mídia livres, os fóruns sociais mundiais, além das organizações paramilitares que vinculam aos seus projetos políticos a resistência à "tirania das marcas", tais como o Exército Zapatista de Libertação Nacional, no México, ou o Movimento dos Trabalhadores Rurais Sem-Terra no Brasil (KLEIN, 2002; 2003).

A problematização da subjetividade sob signo da produção no contexto do CMI alerta para o crescente enrijecimento da subjetividade. Num mundo em que vivenciamos o extremo recrudescimento do individualismo, a produção de uma subjetividade massificada é vendida como promessa de singularização para milhões de sujeitos. No entanto, mesmo neste contexto de laminação das subjetividades, é possível singularizar no cotidiano, ensejando pequenas práticas que sejam focos de criatividade e de experiências de vida enriquecedoras das relações das pessoas com o mundo. Em sua crescente expansão, é próprio do capitalismo oferecer perigo para si mesmo, abrindo frestas, fendas, fissuras, a força motriz do processo de singularização (CAIAFA, 2000). No entanto, como nos ensinou Guattari, nada está dado, é preciso, a partir da compreensão de que a subjetividade é constantemente produzida, lutar por novos campos de possibilidades, inventando no cotidiano novos modos de existência, novas relações consigo mesmo e com o mundo.

\section{Referências Bibliográficas}

BROECKMAN, A. Médias mineurs - Machines hétérogènes. Chimeres - Le devenir mineur des minorités, Paris, n.42, p.113-122. 2001.

CAIAFA, J. Nosso Século XXI: Notas sobre Arte, Técnica e Poderes. Rio de Janeiro: Relume Dumará, 2000.

CHAUÍ, M. Introdução à história da filosofia: dos pré-socráticos a Aristóteles. v..1,2. São Paulo: Companhia das Letras, 2002. 
COSTA, S. de S. G. Subjetividade e menor-idade: acompanhando o devir dos profissionais do social. São Paulo: Annablume; Fortaleza: Secretaria da Cultura e Desportos, 1998.

DELEUZE, G. Empirismo e Subjetividade: ensaio sobre a natureza humana segundo Hume. Tradução de Luiz. L. Orlandi. São Paulo: Ed.34, 2001.

DELEUZE, G.; GUATTARI, F. Mil platôs - Capitalismo e Esquizofrenia. V.1. Rio de Janeiro: Ed.34, 1995.

OSSE, F. Gilles Deleuze Félix Guattari - Biographie Croisée. Paris: La Découverte, 2007.

FOUCAULT, M. Vigiar e Punir: nascimento da prisão. Tradução de Raquel Ramalhete. Petrópolis: Vozes, 1987.

FREIRE, I. R.. Raízes da Psicologia. Petrópolis: Vozes, 1997.

GARCIA-ROZA. Freud e o inconsciente. Rio de Janeiro: Jorge Zahar Editor, 1988.

GONZÁLEZ-REY, F. Sujeito e subjetividade: uma aproximação históricocultural. São Paulo: Thomson, 2003.

GUATTARI, F. O inconsciente maquínico: ensaios de esquizo-análise. Tradução Constança Marcondes César e Lucy Moreira César. Campinas: Papirus Editora, 1988.

As Três Ecologias. Campinas: Papirus, 1990.

Caosmose: um novo paradigma estético. Tradução Ana Lúcia de Oliveira e Lúcia Cláudia Leão. Rio de Janeiro: Ed. 34, 1992.

. Da produção de Subjetividade. In: I magem-Máquina. PARENTE, A. (org) Rio de Janeiro, 34, 1993. p. 177-191.

GUATTARI, F.; ROLNIK, S. Micropolítica: Cartografias do Desejo. Petrópolis: Vozes, 1999.

KLEI N, N. Sem Logo: a tirania das marcas num planeta vendido. Rio de J aneiro: Record, 2002.

Cercas e Janelas: na Linha de Frente do Debate sobre Globalização. São Paulo: Record, 2003.

LATOUR, B. Jamais fomos modernos: ensaio de antropologia simétrica. Rio de Janeiro: editora 34, 1994.

MANGUEIRA, M. Microfísica das criações parciais - pensamento, subjetividade e prática a partir de Nietzsche e Deleuze. Sergipe: EDUFS/F.Oviêdo Teixeira, 2001.

MELO-JÚNIOR, A.; SANTOS, D. A. A fundação do subjetivo: o hábito para além da Psicologia. Revista do Departamento de Psicologia - UFF, v. 18 - n. 2, p. 69-82, Jul./Dez. 2006.

MIRANDA, L. Subjetividade: A (des)construção de um conceito. In: JOBIM e SOUZA, S. (org) Subjetividade em questão: a infância como crítica da cultura. Rio de Janeiro: Ed.7 Letras, 2000. p. 29-46.

OLIVEIRA, R. M. de. Technology and subjectivity: the agency problem. Psicol. Soc. [online]. Jan/Apr. 2005, vol.17, no.1 [cited 07 May 2006], 
p.56-60. Available from World Wide Web: $<$ http://www. scielo.br/scielo.php?script=sci arttext\&pid=S010271822005000100008\&lng=en\&nrm=iso >; I ISSN 0102-7182.

PAIVA, A. C. S. Sujeito e laço social - a produção da subjetividade na arqueogenealogia de Michel Foucault. Rio de Janeiro: Relume Dumará, 2000.

REALE, G; ANTISERI, D. História da Filosofia: Antiguidade e Idade Média. 4ed. v. 1. São Paulo: Paulus, 1990.

\title{
Endereço para correspondência \\ Leonardo Barros Soares \\ Endereço para correspondência: Faculdade de Psicologia da Universidade Federal do Ceará, Av. da Universidade, 2853, Benfica, CEP 60020-181, Fortaleza, Ceará, Brasil. \\ Endereço eletrônico: leonlbs@yahoo.com.br \\ Luciana Lobo Miranda \\ Endereço para correspondência: Faculdade de Psicologia da Universidade Federal do Ceará, Av. da Universidade, 2853, Benfica, CEP 60020-181, Fortaleza, Ceará, Brasil. \\ Endereço eletrônico: lobo.lu@uol.com.br
}

Recebido em: 24/07/2008

Aceito para publicação em: 04/12/2008

Editor responsável: Anna Paula Uziel

\begin{abstract}
Notas
* Bolsista Pibic/UFC na pesquisa "Entulho imagético ou tesouro educacional? Uma análise da relação mídia e subjetividade no cotidiano escolar", realizada sob a orientação da Profa Dra Luciana Lobo Miranda.

** Doutora em Psicologia pela PUC- RJ.

1 A Escola Cínica têm como seus maiores representantes os filósofos Antístenes, seu fundador, e Diógenes. Este último, radicalizando alguns pontos da filosofia socrática, afirmava categoricamente a ética da autonomia do homem em relação à sociedade, fonte integral das ilusões que desviariam o homem de sua efetivação enquanto animal que busca a felicidade (REALE, 1990). Por seu turno, "o sofista é um professor de técnicas, de política, de virtude e de sabedoria, [...], além disso, eram céticos. Para eles, tudo é por convenção e tudo é opinião; tudo é tal como nos aparece e tal como nos parece; [...]. Em outras palavras, não há por que buscar a verdade, pois esta não existe" (CHAUí, 2002, p.188). Para a importância destas escolas para o nascimento da Psicologia, Cf. também FREIRE (1997, p.32).

2 As escolas pré-socráticas, segundo Chauí (2002), são assim designadas para indicar aquele pensamento cuja preocupação central e cuja investigação central eram a phýsis, palavra grega cuja tradução em português é natureza, ou seja, "a realidade primeira e última, subjacente a todas as coisas de nossa experiência. É o que é primário, fundamental e permanente, em oposição ao que é segundo, derivado e transitório". São elas a Escola Jônica, a Escola Pitagórica ou Itálica, a Escola Eleata e a Escola Atomista. Segundo esta filósofa, as três primeiras Escolas têm em comum o fato de tratarem a phýsis como unitária, diferentemente dos representantes da última Escola. Por esse motivo, Chauí propõe que esta última seja denominada Escola da Pluralidade, na qual se encaixariam os filósofos Demócrito e Leucipo de Abdera, além de Empédocles de Agrigento e Anaxágoras de Clazómena.
\end{abstract}


3 Deleuze e Guattari (1995) questionam o estruturalismo principalmente presente na psicanálise e na linguística, para pensar a linguagem sob o signo do rizoma, onde cadeias semióticas e organizações de poder estão sempre implicadas, atravessando territórios seja das artes, da ciência, da filosofia ou das lutas sociais. 4 Citando textualmente Deleuze, "As relações são exteriores aos seus termos. Isso quer dizer que as idéias não dão conta da natureza das operações feitas sobre elas e nem, particularmente, das relações estabelecidas entre elas. Os princípios da natureza humana, os princípios da associação,são a condição necessária da relação" Deleuze, 2001, p.113)

5 Os princípios de associação citados por Deleuze (I bid.) são: contiguidade, semelhança e a causalidade.

6 “Um rizoma não começa nem conclui, ele se encontra sempre no meio, entre as coisas, inter-ser, intermezzo. A árvore é filiação, mas o rizoma é aliança, unicamente aliança. A árvore impõe o verbo "ser", mas o rizoma tem como tecido a conjunção "e... e... e...". Entre as coisas não designa uma correlação localizável que vai de uma para outra e reciprocamente, mas uma direção perpendicular, um movimento transversal que as carrega uma e outra, riacho sem início nem fim, que rói suas duas margens e adquire velocidade no meio" (DELEUZE; GUATTARI, 1995, p.37).

z “ [...] cabe ressaltar que não há espírito da contemplação em si, como uma substância pré-organizada para sentir os estímulos, pois, repetição material e espírito não preexistem isoladamente antes de considerados em relação. Espírito, ou "alma contemplativa", e vibração material, só existem na relação, no encontro entre corpossensíveis e corpos-vibráteis, sendo sensação e vibração uma coisa só nesta relação, pois a sensação só sente por que vibra, por que é vibração que se conserva; e a vibração só vibra por que sente, por que se torna qualidade de sentir outras vibrações. São forças: força-sensação e força-vibração; e como tais, só existem em relação. (DELEUZE; GUATTARI, 1992 apudJ UNIOR; MELO, 2006, p.71).

$\stackrel{8}{ }$ Guattari faz uso do conceito de polifonia da filosofia da linguagem de Mikhail Bakhtin, para enfatizar o caráter heterogêneo e social da subjetividade. "O pensador russo, em sua teoria sobre a linguagem, adota uma perspectiva dialógica, onde o mundo é permanentemente construído no diálogo que remonta a inúmeras vozes, apontando para uma realidade polifônica. O enunciado proferido por um sujeito, além de ter que ser relacionado com seu contexto para poder ser compreendido, não é em absoluto uma prática individual, visto que, sua fala representa um entrecruzamento de diversas vozes, de diversos discursos que Ihes são anteriores" (MIRANDA, 2000, p.39)

9 Em carta dirigida à Guattari, Deleuze o compara ao empirismo inglês, devido à forma como seu parceiro e interlocutor lidava com os conceitos: "Eu creio que você é um prodigioso inventor de conceitos 'selvagens'. O que me encantava tanto quanto entre os empiristas ingleses, [...] Em todo caso, penso seriamente que nós iremos trabalhar novamente juntos. (tradução dos autores)" ( Deleuze carta a Félix Guattari, não datada, provavelmente inicio dos anos 1980 Deleuze apud Dosse, 2007, p. 67). 